"Great God, bless the young and growing state of Iowa. Bless our senators and representatives and chief officers. Give us a sound currency, pure water and undefiled religion. For Christ's sake, Amen."

With this, there was a round of applause by those who favored the sentiment of the prayer and Mr. Shinn was invited to take a seat by the speaker's side. However, he was so rattled by the applause that he quickly left the chamber. According to Allen Shinn's son, Frank, the minister felt that he had "made himself ridiculous, that he offered a prayer in the legislature that was applauded by the members and that as he marched out of the capitol, members looked him in the face with a glow of smiles which convinced him that he had acted very irreverent and disgraced himself."

But, when Mr. Shinn later talked to Col. Hepburn about the incident, he was told that it was the best and greatest prayer that had ever been offered in any legislature. This prayer was not only published in full in the Des Moines papers, but was also printed in the New York Tribune. And, according to the Burlington Hawkeye, Dec. 10, 1904, "Some time later the general appropriation bill contained an appropriation of $\$ 10.00$ for the prayer offered."

\title{
A FEW FACTS YOU SHOULD KNOW ABOUT YOUR STATE
}

The Iowa State Banner or flag was made from a design drawn by Mrs. Dixie Cornell Gebhardt of Knoxville. The Iowa Daughters of the American Revolution presented it to the 39th General Assembly and it was officially adopted on March 29, 1921. It has three vertical bars of blue, white and red, bearing in the white section an eagle and the state motto, "Our Liberties We Prize and Our Rights We Will Maintain."

The Wild Rose, which is abundant all over Iowa, was adopted as the official State flower by the Iowa General Assembly, May 7, 1897.

The Eastern Goldfinch, Spinus tristis (Linneaus), often referred to as a wild canary, was made the official State bird of Iowa by the General Assembly on March 22, 1933. 
Copyright of Annals of Iowa is the property of State of Iowa, by \& through the State Historical Society of Iowa and its content may not be copied or emailed to multiple sites or posted to a listserv without the copyright holder's express written permission. However, users may print, download, or email articles for individual use. 